\title{
Methodical Practice of Teaching Croatian Language and Literature During the Covid-19 Pandemic
}

\author{
Mirela Šušić \\ Assist. Prof, PhD, Department of Croatian \\ Studies, University of Zadar, CROATIA
}

\section{Abstract}

In exceptional circumstances, such as those that have been caused by the COVID-19 virus pandemic, when schools were closed in order for the protection of human health and teaching were moved to an online environment, the implementation of methodological practice proved to be particularly challenging. Distance learning disabled the usual ways of implementing methodological practice, which automatically encouraged the design and application of new ways and methods of implementation. This allowed the students to realization methodical practice even in extraordinary circumstances, such as those caused by COVID-19. The goal of these new ways and methods, despite the extraordinary circumstances, environment and ways in which teaching is being implemented, is to enable students to acquire the practical knowledge, skills, experience and competencies that are necessary in the teaching profession. The paper deals with the methodical practice of students the Department of Croatistics who have mandatory methodological practice within their university study program of the Croatian Language and Literature at the graduate level. Under normal circumstances, these students, under the guidance of a university professor and a mentor teacher in training schools, implement methodical practice in primary and secondary schools where they get aquainted with the work of teachers and activitely participate in the teaching process. Among other things, the students follow pilot mentoring classes, prepare and conduct classes and actively participate in analyzing the same, which is all part of the methodological practice.

Keywords: methodical practice, teaching Croatian Language and Literature, distance learning, students, Croatistics

\section{Introduction}

In a general sense, methodical practice is a compulsory element of the higher education system which is indispensable in the process of acquiring competencies by 
applying knowledge in practice. However, individual methodical practice refers to a specific teaching subject, and is taking place in primary and secondary schools. The purpose of this practice is to acquire competencies for teaching a particular subject. In individual methodical practice, such as the methodical practice of students of Croatian studies as part of the single-major educational graduate study program in Croatian Language and Literature, students acquire competencies for teaching Croatian Language and Literature, which is the focus of this paper. This practice integrates, shares and demonstrates the means of transferring language and literature-related knowledge according to the requirements of philology, Croatistics and lietarary science, i.e. Croatian Language and Literature. Usually, under normal circumstances, methodical practice requires students visiting primary and secondary schools, where they, under the guidance of a university professor and mentor, actively participate in the organization and realization of the teaching process. The extraordinary circumstances caused by the COVID-19 pandemic have directly affected the ability to perform methodical practice in the usual manner. Given that schools closed and that the usual way of conducting classes was replaced with online classes, it was necessary to design and implement new ways of methodical practice under these changed circumstances. In addition to the elaboration of methodical practice performed by students of Croatian Language and Literature, which has not yet been sufficiently explored in scientific literature, the aim of this paper is to demonstrate and define possible means and methods of methodical practice in exceptional circumstances.

\section{Previous research}

A certain paradox can be observed when looking at the position and status of methodical practice in higher education institutions where it is a compulsory part of study programs on one hand and the fact that, on the other hand, methodical practice is rarely the focus of scientific research. Even though the relevance of methodical practice is unquestionable, which is also why it is legally binding, scientific research on this subject can be rarely found. It is only recently that projects have been launched with the theoretical framework assuming that work-based learning enables the students to expand their acquired competencies and develop the skills necessary to better cope in the working environment, be more independent and to easier find employment. As part of the implementation of European Structural and Investment Funds in the Republic of Croatia in the 2014-2020 financing period, the Ministry of Science and Education, as the first-level intermediate body in the project selection process within the grant awarding procedure and following the call titled "Development, advancement and implementation of professional practice in higher education" (URL 1), adopted the Funding Decision (URL 2) regarding multimillion projects of the European Social Fund implemented as part of the Operational Program for Effective Human Resources 2014 - 2020". Following this Funding Decision (URL 
2), several higher education institutions ${ }^{1}$ in the Republic of Croatia have been granted 28 projects with the common objective of developing investments in four key areas: employment and labour market, social inclusion, education and lifelong learning as well as supporting public administration and thereby contributing to employment growth and strengthening social cohesion in Croatia. ${ }^{2}$

The target groups of this project include teaching and non-teaching staff in higher education institutions, students of undergraduate, graduate and integrated undergraduate and graduate study programs. The project aims at improving the quality of professional practice as a compulsory or elective part of the study program, strengthening the competencies of higher education staff to develop a work-based learning model and enabling students to gain work experience by increasing the share of professional practice as a compulsory or elective part of the study program (URL 1).

Regarding the methodical practice of students of Croatian Language and Literature, theoretical reflection thereon can be found in the book titled "Uvod u metodiku, intepretaciju i recepciju književnosti" ("Introduction to Methodology, Interpretation and Reception of Literature") where in the chapter on methodical practice the authors ${ }^{3}$ define and distinguish three types of methodical practice by scientifically observing their essential and distinctive characteristics: methodical, teaching and school practice.

Methodical practice is the process of acquiring methodical experience which can take place during but also outside class, i.e. during methodical practicals as part of a methodics subject and as a simulation of the teaching process, i.e. a simulation of class segments.

Teaching practice can take place at any level of education: primary, secondary or higher education - it can regard faculty, university or polytechnic teaching as well.

School practice is the process of acquiring methodical experience that takes place in primary or secondary schools (Musa et al. 2015: 281).

Given the insufficient literature on methodical practice, this paper is, inter alia, based on the author's ten years' experience in the organization and implementation of methodical practice of students of Croatian Language and Literature at the Department of Croatian Studies, University of Zadar as well as on the implementation

\footnotetext{
${ }^{1}$ Titles of approved projects, names of higher education institutions to carry out the approved projects and their partner institutions involved in the research covered by the projects in question can be found in the Funding Decision (URL 2).
}

\footnotetext{
${ }^{2}$ More information available in: "European Social Fund - Operational Program Efficient Human Resources 20142020 " https://strukturnifondovi.hr/wp-content/uploads/natjecaji/razvoj--unapredenje-i-provedba-strucneprakse-u-visokom-obrazovanju-8809/Upute-za-prijavitelje.pdf. (Accessed 5/7/2020).

${ }^{3}$ In the chapter on methodical practice, Šimun Musa, Mirela Šušić and Marko Tokić present summarized examples of possible methodical practice records for university students to keep during methodical practice in primary and secondary schools as well as examples of written lesson plans for a Croatian Language class.
} 
of methodical practice during the COVID-19 pandemic, when the students were unable to fully perform the methodical practice in the standard manner. Even though schools closed, classes in Croatia continued to be held remotely, via the Internet and television programs, which encouraged the development of new means and methods of implementing methodical practice which will be presented in this paper and which may be useful in the same or similar situations in the future.

\section{General features of methodical practice}

The broad lines of methodical practice implemented in primary and secondary schools in the Republic of Croatia are defined in the legislation. Methodical practice is implemented through study programs in higher education institutions in the Republic of Croatia through compulsory methodics subjects. Methodical practice performed in primary and secondary schools is directly or indirectly regulated by three basic regulations as follows: Primary and Secondary School Education Act (Official Gazette Nos. 87/2008, 86/2009, 92/2010, 105/2010, 90/2011, 5/2012, 16/2012, 86/2012, 126/2012, 94/2013, 152/2014, 07/2017, 68/2018, 98/2019 and 64/2020), Ordinance on practice-schools in primary education (Official Gazette No. 40/199) and Ordinance on practice-schools in secondary education(Official Gazette No. 11/1994). ${ }^{1}$

The fact that the position of methodical practice in the educational system of the Republic of Croatia is regulated by law is the best proof of its relevance. Consequently, one of the legal requirements for a person to establish an employment relationship in a school institution as a subject teacher in a primary school and as a subject teacher in a secondary school is the acquired pedagogical, psychological, didactic and methodical education and a minimum of 55 ECTS credit points, i.e. pedagogical competencies $^{2}$ which, inter alia, in its "methodical" component require the

\footnotetext{
${ }^{1}$ At the end of this paper, in the references, the names of laws, regulations and decisions, as well as all other Croatian sources used in the paper, are listed first originally in Croatian, and then in English.

${ }^{2}$ Pursuant to provisions of Article 105 (6) of the Primary and Secondary School Education Act (Official Gazette Nos. 87/2008, 86/2009, 92/2010, 105/2010, 90/2011, 5/2012, 16/2012, 86/2012, 126/2012, 94/2013, 152/2014, $07 / 2017,68 / 2018,98 / 2019$ and $64 / 2020$ ), the duties of a subject teacher in a primary school may be performed by
} a person who has completed:

a) an educational study program of the appropriate subject at a graduate university level or integrated undergraduate and graduate university study program,

b) an appropriate study program at the graduate university level or an integrated undergraduate and graduate university study program or an appropriate specialist graduate tertiary education study program and acquired the necessary pedagogical, psychological, didactic and methodical education and obtained a minimum of 55 ECTS credit points (hereinafter: pedagogical competencies), if the person referred to in point (a) of this paragraph does not apply for this position,

- four-year undergraduate specialist study program of primary education with an intensified program of the relevant subject or integrated undergraduate and graduate university study program of primary education with a teaching module of the appropriate subject, if the person referred to in point (a) of this paragraph does not apply for this position.

c) - an undergraduate university study program or tertiary education study program where 180 ECTS credits are obtained and acquired pedagogical competencies, if the person referred to in points (a) and (b) of this paragraph does not apply for this position.

Pursuant to the provisions of Article 105 (7) of the aforementioned Act, the duties of a subject teacher in a secondary school may be performed by a person who has completed an appropriate graduate university study program or a graduate specialist tertiary education study program and has the necessary pedagogical competencies. 
completion of a methodical practice as part of compulsory methodics subjects in higher education institutions.

The broad lines of methodical practice implemented in primary and secondary schools certainly are practice-schools, mentors and university methodology professors. The procedure which a school, either primary or secondary, undergoes in order to become a practice-school where the students will carry out the methodical practice, i.e. the procedure which a teacher undergoes in order to obtain the status of a mentor who will guide the students through the practice is also regulated by law.

Schools become practice-schools upon a proposal by higher education institutions which prepare the students for educational work involving pupils. In the administrative procedure, the Ministry of Science and Education verifies and determines if the proposed school fulfills the requirements and work modes to become qualified as a practice-school. Pursuant to the Ordinance on practice-schools in primary education (Official Gazette No. 40/1991), to be declared as a practiceschool, a primary school must fulfill the following requirements:

- be in the same location as the faculty

- have a space in which up to 25 pupils and up to 15 students can work at the same time

- have specialized classrooms, offices, space for demonstration and performance of various forms

- and contents of educational and rehabilitation work in single-class and multiclass

- departments as well as for student counseling and other activities

- have sufficient didactic and rehabilitation aids and equipment, an office with

- IT and other modern equipment for carrying out educational work

- have developed forms of extracurricular activities and other forms of public and cultural activities

- have the appropriate staff. A primary school or other organization is declared as a practice-school

- by the Ministry of Education and Culture, upon a proposal by the Institute for Education and the Faculty.

- Pursuant to the Ordinance on practice-schools in secondary education (Official Gazette No. 40/1991), to be declared as a practice-school, a school must fulfill the following requirements:

- one or more faculties in the field of education submitted a proposal for the school to become a practice-school 
- have the possibility of performing methodical exercises in at least one subject,

- have designated mentors for particular subjects,

- have the necessary equipment, space and teaching aids for the subjects referred to in indent 2 of this paragraph and

- is willing to fulfill the tasks of a practice-school.

The fulfillment of the requirements referred to in paragraph 1 of this Article shall be determined by the Institute for Education of the Ministry of Culture and Education. If it stops fulfilling any of the requirements referred to in paragraph 1 of this Article, the Minister shall annul the decision declaring the school a practice-school.

Upon the completion of the procedure and the verification, the line ministry issues an approval decision and defines the financing criteria or, in the case of non-fulfillment of these requirements, issues a rejection. Schools are declared pratice-schools for a certain period of time. Schools which have successfully undergone the procedure obtain an approval from the Ministry of Science and Education declaring them practice-schools.

In schools which become practice-schools, and upon the proposal of higher education institutions, the line ministry appoints individual teachers as students' mentors. In order to become a students' mentor, a teacher must meet the criteria of professional expertise and have gained affirmation in their educational work. Students' mentors in secondary schools can only be those teachers who have become mentors or advisors as part of a special procedure and have a formal document ${ }^{1}$ attesting that, which is issued by the competent institution for a certain period of time, and is regulated by the Ordinance on the promotion of teachers, professors, professional associates and principals in primary and secondary schools and student dormitories (Official Gazette No. 68/2019).

Every methodical practice carried out in primary and secondary schools aims at enabling the students to gain practical experience by actively taking part in the teaching process. Active participation in the teaching process means including the students in all forms of educational and rehabilitation work provided in the curriculum of the higher education institution which can be carried out in the practice-school. The purpose of methodical practice is achieved through enabling the students to use their didactic, methodical, pedagogical, psychological and defectology knowledge in practice in the immediate educational work and instructing them how to carry out the individual phases of educational work in practice. Special attention is

\footnotetext{
${ }^{1}$ Article 8 of the Ordinance on practice-schools in secondary education (Official Gazette No. 11/1994) stipulates the following: "Mentoring tasks and tasks in practice schools shall be performed by mentors and advisors. Exceptionally, when the practice-school does not have a mentor or advisor for the subject in which the methodical exercises will be performed, the principal may conclude an employment contract with a mentor employed in another school or, in agreement with the methodology professor, temporarily entrust the mentoring tasks to a teacher who does not have the title of a mentor, however, for a maximum of one school year."
} 
given to introducing the students to planning and organizing teaching content and choosing the means and methods to carry it out. Preparing and teaching units as well as monitoring and evaluating educational work play an important role in methodical practice. The purpose of methodical practice is also achieved through introducing the students to the application of innovations and modern teaching technologies in educational work, developing their interest for and professional attitude towards educational and rehabilitation activities and developing specific professional abilities required for the work in extracurricular activities. The particular significance of methodical practice also lies in introducing the students, as future teachers, to laws and ordinances regulating the entire educational process, which enable them to familiarize themselves with the context of rights and obligations of all the stakeholders in the educational process.

Each individual methodical practice carried out in primary and secondary schools must bring together all the aforementioned broad lines.

\section{Organization and performance of methodical practice in normal circumstances}

In addition to its general features regulated by legislation, methodical practice has its very specific characteristics depending on the study program and subject in question.

When it comes to methodical practice of students of Croatian Language and Literature in the educational study program, methodical practice is carried out in primary and secondary schools, preceded by complex organization. The methodical practice is organized by a university methodology professor, who, depending on the number of students which changes yearly as well as the needs of the study program, communicates the need for a certain number of practice-schools and mentors to the administrative body of their higher education institution. After that, the higher education institution initiates the procedure of proposing practice-schools and mentors, which is previously determined in the broad lines of the methodical practice. Due to the length of the procedure, taking care of time management is especially important in order to achieve compliance with all legal regulations before starting the practice. After appointing practice-schools and mentors, the university methodology professor organizes students into smaller groups and coordinates their visits to practice-schools and their meetings with the mentors.

At the beginning of the academic year, and in accordance with the curriculum of the study program, a specific time period is determined within the academic year, in which the methodical practice is carried out. The university issues a verified referral to each student and thus refers a student to the methodical practice at the appointed practice-school with the specific mentor. The referral prescribes a precise time period within which the student must carry out the practice. Following the conclusion of the practice, the practice-school verifies the referral as proof of a properly and successfully performed practice. 
The methodical practice of the students of Croatian Language and Literature in the educational study program is aimed at familiarizing the students with the practice of teaching Croatian language, literature, linguistic expression and media culture, as well as training them to teach the aforementioned.

The main content of the methodical practice refers to familiarizing oneself with teaching duties and responsibilities as well as curricula (bases of teaching), textbooks, acts, ordinances and school documentation. Observing mentors' lessons and other teaching duties. Participating in analyses and evaluation of teaching hours, creating a monthly implementation plan for the subject Croatian Language. Independent creation of written tasks for testing and evaluating the knowledge, achievements and abilities of pupils in primary and secondary schools. Written lesson plans. Teaching classes (lectures).

At the beginning of methodical practice, the students must observe a determined number of demonstration lectures held by their mentors. Since the subject Croatian Language has three educational areas ${ }^{1}$, a mentor from each area performs multiple demonstrational lectures that serve as an example of how students should teach a lesson. During the methodical practice, students keep a methodical practice record in which they record demonstrational lectures, make notes on the lessons, familiarize themselves with the duties of a teacher, note all relevant observations, own analyses, records of their own and their colleagues' attendance at the methodical practice, as well as all their performed duties. Following the conclusion of the practice, mentors verify methodical practice records, and the students are obliged to submit their records to the university methodology professor.

Mentors and students coordinate the schedules for observing methodical lessons, students' lessons (trial and demonstrational) and other obligations, and the schedule states how many lessons the students have to observe and actively participate in, that students have to prepare and carry out the lessons, actively participate in the analyses of the lessons, keep a methodical practice record, carry out all duties and set tasks within the methodical practice (lectures at the faculty).

In accordance with the instructions from the university methodology professor, the students, together with their mentors, write their lesson plans for the practice and give special attention to it. For the purpose of trial and demonstrational lessons, students write lesson plans, which represent a certain scenario planned for the lesson. The plan includes all relevant segments of the lesson, such as lesson type, educational area, unit, methodical system, motivation, methods and ways of realization, aims, objectives and learning outcomes.

\footnotetext{
${ }^{1}$ Pursuant to the Decision on the adoption of the curriculum for the subject Croatian Language for primary schools and grammar schools in the Republic of Croatia (Official Gazette Nos. 87/08, 86/09, 92/10, 105/10 - correction, $90 / 11,16 / 12,86 / 12,94 / 13,152 / 14,7 / 17$ and 68/18), the subject Croatian Language is organized in three interrelated subject areas: Croatian language and communication, literature and creation, culture and media.
} 
After the students have observed mentors' demonstrational lectures, they carry out their own trial lessons that enable them to gain experience by directly teaching a lesson that is not graded, the aim of which is to prepare students for the demonstrational lesson and their future independent work. During the trial lessons, if necessary, mentors can intervene and comment on the students' lesson performance. Demonstrational lessons are carried out independently, without mentor's interventions, and after the end the lesson, comments and analyses are provided. Students are obliged to observe and analyze trial and demonstrational lessons of their colleagues because group work is necessary to evaluate and analyze particular segments of the lesson together. Therefore, group work is inevitable for establishing the conditions for this kind of collaborative learning. Students analyze demonstrational lessons together with the mentor, university professor and other colleagues from their group.

During the methodical practice, students create their personal portfolio in which they collect professionally relevant documents on the increase of their own teaching competence, such as methodical practice record, samples of lesson plans, mentor's assessment of the quality of the student's independent lesson, self-evaluation of each carried out lesson and achieved teaching competence, copies of independently made, written lesson plans and other teaching materials.

Within the methodical practice, students become familiar with creating a monthly and yearly implementation plan for the subject Croatian Language. They create written tasks to independently test and assess the knowledge, achievements and abilities of pupils in primary and secondary schools. They create a number of written lesson plans and get acquainted with textbooks, curricula, and the processes of their creation, as well as with acts, ordinances and school documentation with all relevant pedagogical documentation which regulates teachers' duties and obligations.

Students are obligated to regularly and actively comply with the schedule of mentors' lessons, observe, prepare and carry out the planned lessons, actively participate in the analyses of their and their colleagues' lessons, keep a methodical practice record, carry out the tasks set within the practice (faculty lessons) and fulfill all obligations within the methodical practice.

The control of the success of the methodical practice is expressed in the final grade, which is based on the continuous monitoring of the students during methodical practice, and which is derived from several elements such as: quality of lesson plans for demonstrational lessons, practice record, participation in lesson analyses, carrying out tasks within the practice, regularity of methodical practice attendance, active participation in practice which includes practice record analyses and lesson simulation (university lectures) and participation in the analysis of these lessons, and attitude towards work, pupils, as well as all participants in the educational process. 
The mentor and the university methodology professor together evaluate the demonstrational lesson of each individual student, and the final methodical practice grade is decided on by the university methodology professor, based on the mentor's report on each individual student and their own insight into the activity of each individual student during the methodical practice, as well as the personal portfolio of each individual student.

After successfully completing the methodical practice, students are able to:

- independently plan, perform, analyze and evaluate a Croatian Language and Literature class in primary and secondary schools

- independently create teaching units in the field of literature and language in a methodical manner by integrating literary, literary and historical, literarytheoretical and linguistic contents within different teaching systems

- make substantiated decisions on selecting appropriate teaching materials, teaching methods and practices, teaching equipment and tools, and social forms of work in accordance with the teaching context

- describe and explain each individual component of communicational, referential instruments relating to teaching language and literature in primary and secondary schools

- substantiate current requirements and needs regarding the teaching of Croatian Language and Literature in primary and secondary schools

- connect the teaching of literature with other areas of artistic work

- analyze examples of interdisciplinarity in literature teaching

- analytically and critically evaluate the process of teaching Croatian Language and Literature

- independently create teaching materials

- consider and design the Croatian Language and the Croatian Literature class from several points of view

- synthesize achievements of certain schools of methodology and actively apply different methods when teaching literature.

\section{Means and methods of implementing methodical practice in extraordinary circumstances}

The period of participating in methodical practice, even in normal conditions, was shown to be stressful for students, based on the ten-year experience in the organization and implementation of methodical practice at the University of Zadar, Department of Croatian Studies, during which approximately 400 students were referred to practice, guided and observed. In the largest number of students, positive 
excitement was present because they had the opportunity to try out their abilities in the real school environment. However, stage fright was present in a smaller number of students because of the exposure to practical teaching work which implies a direct exposure of the student in front of the pupils, mentor and university professor. A certain pressure in students is created by being aware that during a literature class, they can clearly demonstrate the total accumulation of their previously (not) acquired knowledge. In such cases, stage fright is regularly and successfully eliminated by collaborative learning ${ }^{1}$ and application of affirmative methods and means. However, in addition to this usual phenomenon of emotional dimension present during methodical practice that can be successfully controlled, methodical practice, as a complex process which includes numerous different institutions and a large number of participants, is also disrupted by the COVID-19 virus.

Since schools and higher education institutions had to be closed to stop the spread of the COVID-19 pandemic, classes were no longer held in person. They were held in an online environment and via television programs, in a completely different manner and in a completely different social context. Distance learning prevented students of Croatian Language and Literature, who in the period of the pandemic were in the process of carrying out methodical practice, from finishing their ongoing practice in schools. Such a new situation has encouraged reflection and raised the question of how to complete the implementation of students' methodical practice, i.e. how can the practice be compensated without endangering the academic standards or compromising the defined objectives of methodical practice learning. Quickly, it became evident that online learning, i.e. learning by using different applications, can be challenging to the most experienced and computer literate teachers considering that this is a completely new teaching method, and that this new method is surprisingly very familiar to students. In addition, using certain applications and online learning tools alone is a way of acquiring knowledge on teaching in methodical terms.

An idea was found to include students through their mentors in all components of remote learning so that they could acquire pedagogical competences by participating in the class process as it actually was at the given moment - online! It was noticed that this way, students can be useful to society at the same time, because through their own learning process, they will help their mentors ${ }^{2}$, pupils' parents who also had to

\footnotetext{
${ }^{1}$ Collaborative or cooperative learning is the joint learning of pupils in pairs or small groups with the aim of solving common tasks, examining and exploring a common topic or building onto their insights to create and develop new ideas, new combinations or a unique innovation (Meredith et al., 1998). Collaborative learning is one of the fruitful areas of theory, research and practice in education, and it implies joint activity of pupils with the aim of achieving common educational objectives (Johnson and Johnson, 1998).

${ }^{2}$ Mentors showed a special fondness of this way of cooperation because students have proved themselves to be responsible, diligent, enthusiastic and innovative during the methodical practice that had started in the normal circumstances, which showed their mentors that they were serious, and because engagement of the students proved to be an immense help in online learning.
} 
be included in the teaching process, and especially the pupils, who also found themselves in the same situation as the students, which created social empathy.

An important feature of methodical practice realized through online learning is social distancing, thanks to which the students and all other participants of the learning process are protected. Using the previously agreed upon application, either by the university or practice-school, students can observe demonstrational classes held by their mentors. Own trial and demonstrational classes can be carried in several ways, either online, in real time, directly including the pupils, mentors and university professor, or by recording a video and uploading it to a plafrom, i.e. a previously agreed upon channel. A huge advantage of conducting the evaluation of demonstrational classes online, which is done by the mentor and university professor, is the elimination of physically going to school, which is significantly less timeconsuming. The distribution of all teaching materials between all participants of the methodical practice was accelerated, and the availability and storing of the materials (written lesson plans, quizzes prepared for the class, questionnaires and surveys, motivational materials, practice materials, literary texts, linguistic analysis materials etc.) were simplified. For the purpose of covering certain teaching units and in agreement with their mentor, students can design methods and implement them into remote learning and suggest solutions for certain segments of the language and literature class, thereby helping their mentor to prepare classes and gaining experience. Students can upgrade mentors' existing lesson plans with images, audio, animations and video. The possibilities are endless, and they depend solely on the activity and creativity of each student and the openness of mentors. It often happens that a student is familiar with teaching tools and applications that can advance and improve the class, and thus motivate pupils. Including students to help in carrying out pupils' projects is an excellent method for interaction and encouraging pupils' creativity and independence, as well as for extracurricular activities which contribute to general growth and development.

Students can be a great help to their mentors in technical sense as well, by uploading their already prepared materials for teaching, as well as recorded classes. The fact that students find materials and content on the internet, when libraries are closed due to the pandemic, helps teachers and contributes to the quality of the work. Checking pupils' homeworks under mentors' supervision enables students to gain experience in the area of evaluation. The students' help in the supervision of pupils during online exams is of great significance.

Carrying out the methodical practice online has its advantages. The university methodology teacher has an insight into students' and mentors' performance in a quick and efficient manner, and this information is collected on the university's internet platform that was specified, approved or recommended. Reaction time regarding any potential irregularities is prompt, and the insight into the implementation of methodical practice is absolute because everything that 
"happens", happens in an online environment, in whose nature it is to record everything, and the insight is not conditional on time. The ability to attend multiple practice-schools at once gives a completely new significance to methodical practice and provides completely new opportunities giving the integrational and correlational methodical system a prominent role. The ability to store all processes of methodical practice could be useful for university lectures in methodics subjects, as well as for scientific research.

\section{Conclusion}

In the Republic of Croatia, in all programs of Croatian Studies of the Educational Study Program, methodical practice is represented through compulsory subjects in the field of language methodology and literary methodology. In normal conditions, students from the Department of Croatian Studies of the University of Zadar carry out their methodical practice in a real environment - when they physically visit a primary or secondary school, organized and guided by the universty professor in cooperation with the mentor teacher in the practice-school. According to the program of the compulsory methodics subject within which the methodical practice is carried out and organized, students have a prescribed schedule for methodical practice. The obligations of students and mentors which need to be fulfilled during the practice are precisely defined. Students visit primary and secondary schools to practice because they are studying to become subject teachers in primary schools, and teachers in secondary schools.

When organizing and implementing methodical practice for the students of Croatian Language and Literature, there are constant efforts to upgrade and advance the practice. However, when the conditions arise that prevent such practice form realization, it is necessary to be open to new possibilities, and if there are not any, to create them under given conditions.

The motivation inspired by the desire not to deprive students of the practical part of their education and of their right to complete their task in real time, without having to make up the lost time, which is already uncertain due to the nature of the pandemic, resulted in the organization, implementation and realization of methodical practice through online classes. The awareness of the potential help that students can and want to provide to mentors, pupils and pupils' parents, at the same time gaining teaching competences without safety concerns, has contributed to the decision to start a different method of methodical practice realization, which maintains academic standards and achieves the planned teaching objectives regardless of the new way of implementation.

In addition to the fact that such new approach to methodical practice enables students to carry out their methodical practice in extraordinary circumstances, being useful to society at the same time, it will certainly be a significant supplement and upgrade to the study program. 
After the initial demanding processes involving the organization, implementation and realization of methodical practice as part of online classes, thus affirming highly useful and practical methods and means enabled this way, as well as the potential for university teaching and scientific research, in contrast to the standard methodical practice, one thing remains. It is the unshaken awareness of the most important methodical fact that the spoken word of a teacher, social contact and the emotion provoked by the real school environment are irreplaceable!

Based on the experiences and insights gained from the COVID-19 pandemic, it is possible and necessary to think about the possibility of combining methodical practice in its standard form performed in normal circumstances with methodical practice realized through online classes, depending on the circumstances.

To conclude, methodical practice in online classes, which began due to the COVID-19 pandemic, can be seen as a supplement and upgrade to methodical practice in a general sense, as well as a possible solution to each individual practice carried out in primary and secondary school in extraordinary circumstances. The purpose of such methodical practice is to, in extraordinary circumstances regardless of their cause, enable students to start applying theoretical knowledge acquired during their studies in practice, and to train them to convey their knowledge to pupils. Working directly in classes with pupils and a mentor, continuous collaboration and consulting with a university methodology professor, spending time in a real school environment where the teaching process happens live and in a real environment and real time all encourage more complex reflections on class performance and provide the opportunity for students to directly compare themselves to a professional mentor and colleagues with the same level of education and experience. Regardless of the method of its implementation, methodical practice is an indispensable segment of the higher education system. Therefore, it is important that there are defined and different ways to implement methodical practice in extraordinary circumstances regardless of their cause, in addition to the existing, standard way of its implementation, i.e. by students visiting primary and secondary schools in normal circumstances.

\section{References}

[1] "Europski socijalni fond Operativni program Učinkoviti ljudski potencijali 2014. - 2020."

[2] "European Social Fund - Operational Program Efficient Human Resources 2014-2020"

[3] https://strukturnifondovi.hr/wp-content/uploads/natjecaji/razvoj-unapredenje-i-provedba-strucne-prakse-u-visokom-obrazovanju8809/Upute-za-prijavitelje.pdf. (Accessed 5/7/2020).

[4] Johnson, D. W.; Johnson, R. T. (1998). "Cooperative Learning”. In: Returns to College Chang, 30(4), pp 26-35. 
[5] Meredith, K. S.; Steele, J. L.; Temple, C. (1998). Cooperative Leading and Writing for Critical Thinking - RWCT. University of Nothern Iowa \& International Reading Associations.

[6] Musa, Š.; Šušić, M.; Tokić, M. (2015). Uvod u metodiku, interpretaciju i recepciju književnosti. [Introduction to Methodology, Interpretation and Reception of Literature

[7] Zadar: Sveučilište u Zadru. (Accessed 2/7/2020).

[8] Odluka o donošenju kurikuluma za nastavni predmet Hrvatski jezik za osnovne škole i gimnazije u Republici Hrvatskoj (Narodne novine broj: 87/08, 86/09, 92/10, 105/10 - ispravak, 90/11, 16/12, 86/12, 94/13, $152 / 14,7 / 17$ i $68 / 18)$.

[9] Decision on the adoption of the curriculum for the subject Croatian Language for primary schools and grammar schools in the Republic of Croatia (Official Gazette Nos. 87/08, 86/09, 92/10, 105/10 - correction, 90/11, 16/12, 86/12, 94/13, 152/14, 7/17 and 68/18)

[10] https://narodne-novine.nn.hr/clanci/sluzbeni/2019_01_10_215.html. (Accessed 9/7/2020).

[11] Pravilnikom o napredovanju učitelja, nastavnika, stručnih suradnika i ravnatelja u osnovnim i srednjim školama i učeničkim domovima (Narodne novine, broj 68/2019).

[12] Ordinance on the promotion of teachers, professors, professional associates and principals in primary and secondary schools and student dormitories (Official Gazette No. 68/2019)

[13] https://www.nszssh.hr/pdf/Pravilnik\%20o\%20napredovanju\%20NN\%206 8\%20od\%2017\%20srpnja\%202019.pdf.(Accessed 2/7/2020).

[14] Pravilnik o vježbaonicama u osnovnoj školi (Narodne novine, broj 40/1991). [Ordinance on practice-schools in primary education (Official Gazette No. 40/1991)

[15] https://www.azoo.hr/images/stories/dokumenti/propisi/Pravilnici_11.pdf. (Accessed 3/7/2020).

[16] Pravilnik o vježbaonicama u srednjim školama (Narodne novine, broj 11/1994). [Ordinance on practice-schools in secondary education (Official Gazette No. 11/1994)

[17] https://narodne-novine.nn.hr/clanci/sluzbeni/1994_02_11_218.html. (Accessed 4/7/2020).

[18] URL1:https://strukturnifondovi.hr/en/natjecaji/razvoj-unapredenje-iprovedba-strucne-prakse-u-visokom-obrazovanju/ (Accessed 1/7/2020).

[19] Funding Decision of the Ministry of Science and Education of the Republic of Croatia of 17 February 2020, CLASS: 910-08/19-01/00020, REG. NO.: 53306-20-0016 
[20] URL 2: Odluka o financiranju Ministarstava znanosti i obrazovanja Republike Hrvatske od 17. veljače 2020.,KLASA: 910-08/19-01/00020, URBROJ: 53306-20-0016.

[21] https://strukturnifondovi.hr/wp-content/uploads/2018/05/UP.03.1.1.04Odluka-o-financiranju-Razvoj-unaprje\%C4\%91enje-i-provedbastru\%C4\%8Dne-prakse-u-visokom-obrrazovanju.pdf. (Accessed 2/7/2020).

[22] Zakona o odgoju i obrazovanju u osnovnoj i srednjoj školi (Narodne novine, broj $87 / 2008,86 / 2009,92 / 2010,105 / 2010,90 / 2011,5 / 2012,16 / 2012$, 86/2012,126/2012, 94/2013, 152/2014, 07/2017, 68/2018, 98/2019 and 64/2020). [Primary and Secondary School Education Act (Official Gazette Nos. 87/2008, 86/2009, 92/2010,105/2010, 90/2011, 5/2012, 16/2012, $86 / 2012,126 / 2012,94 / 2013,152 / 2014,07 / 2017,68 / 2018,98 / 2019$ and 64/2020).

[23] https://www.zakon.hr/z/317/Zakon-o-odgoju-i-obrazovanju-u-osnovnoj-isrednjoj-\%C5\%A1koli. (Accessed 1/7/2020). 